\title{
Comparing Estimation Methods for Soil Organic Carbon Storage in Small Karst Watersheds
}

\author{
Zhenming Zhang, ${ }^{1,2}$, Yunchao Zhou ${ }^{2,3 *}$, Shijie Wang ${ }^{3,4}$, Xianfei Huang ${ }^{1,2}$ \\ ${ }^{1}$ Forest Resource and Environment Research Center of Guizhou Province, Guizhou University, Guiyang, P.R. China \\ ${ }^{2}$ College of Forestry, Guizhou University, Guiyang, P.R. China \\ ${ }^{3}$ Puding Karst Ecosystem Research Station of Guizhou Province, Puding, P.R. China \\ ${ }^{4}$ State Key Laboratory of Environmental Geochemistry, Institute of Geochemistry, \\ Chinese Academy of Science, Guiyang, P.R. China
}

Received: 22 June 2017

Accepted: 21 September 2017

\begin{abstract}
In order to accurately estimate soil organic carbon storage (SOCS), 2,755 soil profiles and 23,536 soil samples were acquired by grid method, followed by a study on the SOCS, soil bulk density (SBD), gravel content (GC), and distribution characteristics of rock coverage (RC) in a small karst watershed (SKC). Then on the basis of soil profile summation, an investigation was done on the applicability of RC/GC-based soil type method, land utilization type method, and aspect method to the estimation of SOCS in SKC at different depths. As shown by the results, the average soil organic carbon content (SOC) in the soil samples ranged from 5.25 to $24.87 \mathrm{~g} . \mathrm{kg}^{-1}$, and decreased with the soil depth increasing; the average SBD ranged from 1.17 to $1.41 \mathrm{~g} . \mathrm{cm}^{-3}$, which first increased with the soil depth increasing and then tended to be steady; the average GC ranged from 0 to $20.15 \%$, which decreased gradually with the soil depth increasing and finally to zero; the RC ranged from 0 to $86.32 \%$ at different sample points. RC and GC greatly affected the estimation of SOCS, so after correction based on RC and GC, the soil type method was adopted for estimation, concluding that SOCS at depths of 0-20 $\mathrm{cm}, 0-30 \mathrm{~cm}$, and $0-100 \mathrm{~cm}$ was $341.82 \times 10^{6} \mathrm{~kg}, 449.29 \times 10^{6} \mathrm{~kg}$, and $738.351 \times 0^{6} \mathrm{~kg}$, respectively; $\mathrm{RC}$ and GC affected white sandy soil the most, as shown by the following SOCS estimated by the land utilization type method: $319.56 \times 10^{6} \mathrm{~kg}, 416.04 \times 10^{6} \mathrm{~kg}$, and $607.02 \times 10^{6} \mathrm{~kg}$, respectively, at depths of 0-20 cm, 0-30 cm, and 0-100 cm; RC and GC affected wasteland the most, as shown by the following SOCS estimated by the aspect method: $318.64 \times 10^{6} \mathrm{~kg}, 411.63 \times 10^{6} \mathrm{~kg}$, and $628.46 \times 10^{6} \mathrm{~kg}$, respectively, at depths of 0-20 cm, 0-30 cm, and 0-100 cm; RC and GC affected the SOCS in the south slope the most; in terms of catchment scale, the "vertical stratification + horizontal classification" pattern was expanded to the "land utilization type method" and "aspect method." For estimating the SOCS in topsoil, the aspect method achieved the best result, while the land utilization type method achieved the best result at a depth of $100 \mathrm{~cm}$.
\end{abstract}

Keywords: estimation method, soil organic carbon storage, true value, small watershed, karst

*e-mail: yczhou@gzu.edu.cn 


\section{Introduction}

Soil is the largest and most active carbon reservoir in the terrestrial ecosystem and is the focus of research into the global carbon cycle and climate change [1]. The function of soil as a carbon source/sink is irreplaceable for adjusting the global carbon balance and slowing the increase in greenhouse gas concentrations. Small changes to the soil carbon reservoir could lead to significant impacts on the global climate [2]. Thus, it is important to accurately estimate soil organic carbon storage. Scientifically and accurately estimating soil organic carbon storage is the focus of and challenge in current research into the carbon cycle [3]. Currently, there are numerous methods of estimating soil organic carbon storage at various scales and depths, the main methods being soil taxonomy methods, GIS estimation, and land use methods - all of which are based on data including soil profiles, world soil maps, and vegetation and land use maps [4]. The soil taxonomy method is based on soil properties and the organic carbon content in a unit area of each soil type according to soil profile data [5]. Then, according to the classification of aggregated soil layer profiles, one finally obtains a total soil organic carbon content based on the area's extent of each soil type. This method focuses on soil types and does not take into account differences among various regional ecosystem scales and the spatial variability of soil organic carbon [6]. In the land use method, one calculates soil organic carbon storage based on soil organic carbon density and the areal extent of each ecosystem type, which yields the total amount of soil organic carbon storage depending on patterns of vegetation, ecosystems, and subsurface factors. Karst areas, however, due to their special geologic setting and complex topography and geomorphology, are characterized by broken terrain, complex landscapes, and great soil heterogeneity [7]. Their soil types and land use patterns vary with the slope aspect, leading to a highly varied organic carbon distribution. Which method yields better estimates of soil organic carbon storage is arguable. Therefore, when estimating the extent of the soil carbon reservoir in karst areas, it is important to select a suitable method of accurately estimating the soil carbon storage and carbon density.

Because karst ecosystems are controlled by their special geological setting, their geomorphology and landscape, hydrothermal conditions, vegetation conditions, and soil formation conditions differ from those of non-karst areas and lead to different characteristics of the local soil carbon cycle [8]. To assess the carbon storage capacity of terrestrial soil ecosystems in China, it is important to understand soil carbon storage in karst areas [9]. Due to the special geological and climate conditions of karst areas, these areas are characterized by small environmental capacity, weak responses to disturbance, low stability, and low self-adjustment ability, and they thus recover slowly following a disturbance [10]. Additionally, the soil conditions in karst areas are characterized by extensive bedrock exposure, small soil stocks, discontinuous soil distributions, and complex and diverse micro-landscapes - all of which lead to numerous uncertainties in the estimation of soil organic carbon storage [11]. Due to the unique characteristics of karst areas, the methods used to estimate the organic carbon stock and organic carbon density in non-karst areas do not work well when applied to karst areas [12]. Currently, when estimating the organic carbon storage in karst areas, a few researchers have paid attention to indicators such as the extent of areas barren of soil and soil thickness, but they do not take into account the combined effects of the gravel content and extent of rock exposure in estimates of soil organic carbon storage [13].

Assessing relevant indicators and obtaining a large number of samples for analysis play vital roles in developing reliable estimates [14]. Thus, the present study focused on the soils in high-elevation rocky parts of small drainage basins of the plateau karst areas [15]. Based on a systematic and comprehensive survey of soil profiles, we calibrated the rock bareness and gravel content of 2,755 soil profiles and applied the soil taxonomy, land use, and slope aspect methods to correct the formula for calculating the organic carbon density and stock and estimated the organic carbon density and stocks corresponding to various soil thicknesses. Based on the method of soil profile summation, we compared the suitabilities of the methods for estimating soil organic carbon stock in the karst area and thus provide scientific support for the research of accurate estimation of the soil organic carbon stocks of a small plateau karst watershed.

\section{Materials and Methods}

Study Region

The study region $\left(105^{\circ} 40^{\prime} 43^{\prime \prime}-105^{\circ} 48^{\prime} 2^{\prime \prime} \mathrm{E}, 26^{\circ} 12^{\prime 2} 29^{\prime \prime}-\right.$ $26^{\circ} 17^{\prime} 15^{\prime \prime} \mathrm{N}$ ) is located in Puding County in the central part of Guizhou Province in southwestern China, including the three towns of Chengguan (CG), Maguan (MG), and Baiyan (BY), and it covers an area of $72 \mathrm{~km}^{2}$. The elevation is between 1,223.4 and 1,567.4 m above sea level, and the air pressure is between 806.1 and $883.8 \mathrm{hpa}$. There are three major categories of soil: limestone, paddy, and yellow. They are all interwoven with each other, so soils in this watershed have high heterogeneity. The limestone soil areas suffering from severe stony desertification are scattered with rock exposure. The vegetation (Table 1) includes cedarwood (Cupressus funebris Endl.), populus adenopoda (Populus Adenopoda Maxim), toona sinensis (Toona sinensis (A. Juss.) Roem.), Chinese pear (Pyrus pyrifolia Burm Nakai.), and so on. The main crops are paddy rice (Oryzasativa Oryzaglaberrima), corn (Zea mays Linn. Sp.), soybean (Glycine max (Linn.) Merr), sunflower (Helianthus annuus), etc. There are 7 soil types of three major categories in the study area: Xan Udic Fernalisols, Black Lithomorphic Isohumisols, Cab Udi Orthic Entisols, Cab High fertility Orthic Anthrosol, Cab 
Table 1. Geographic information of study area.

\begin{tabular}{|c|c|c|c|}
\hline Items & Chengguan Town & Maguan Town & Baiyan Town \\
\hline Precipitation (mm) & $1,170.9$ & $1,178.8$ & $1,396.9$ \\
\hline Temperature $\left({ }^{\circ} \mathrm{C}\right)$ & 15.3 & 15.2 & 15.1 \\
\hline Frostless season (days) & 301 & 289 & 292 \\
\hline Soil thickness $(\mathrm{cm})$ & $6->100(70.14)^{\mathrm{a}}$ & $6->100(57.36)$ & $5->100(58.76)$ \\
\hline Major vegetation & $\begin{array}{c}\text { Tree species: Cupressus } \\
\text { funebris Endl, Broussonetia } \\
\text { papyrifera, Populus Adenopoda } \\
\text { Maxim. } \\
\text { Shrub species: } \text { Pyracantha } \\
\text { floruneana, Itea ilicifolia) }\end{array}$ & $\begin{array}{c}\text { Tree species: Cupressus funebris Endl, } \\
\text { Broussonetia papyrifera, Toona sinensis } \\
\text { (A.Juss.) Roem., Celtis sinensis. } \\
\text { Shrub species: } \\
\text { Rosa cymosa), Zanthoxylum } \\
\text { bungeanumMaxim. }\end{array}$ & $\begin{array}{l}\text { Tree species: Cupressus fune- } \\
\text { bris Endl, (Platycarya longipes, } \\
\text { Pyrus pyrifolia Burm Nakai. } \\
\text { Shrub species: } \\
\text { Pyracantha floruneana, Rosa } \\
\text { cymosa }\end{array}$ \\
\hline Land uses $(\%)$ & $\begin{array}{c}\text { Forestland: } 11.84 \\
\text { Bush forest: } 15.67 \\
\text { Cultivated land: } 56.75 \text { Unused } \\
\text { land: } 5.85 \\
\text { Construction land: } 9.92\end{array}$ & $\begin{array}{c}\text { Forestland: } 14.67 \\
\text { Bush forest: } 22.54 \text { Cultivated land: } \\
49.84 \text { Unused land: } 7.13 \\
\text { Construction land: } 5.82\end{array}$ & $\begin{array}{c}\text { Forestland: } 16.24 \% \\
\text { Bush forest: } 18.33 \text { Cultivated } \\
\text { land: } 54.38 \text { Unused land: } 4.91 \\
\text { Construction land: } 6.14\end{array}$ \\
\hline
\end{tabular}

Note: "a" is the mean value of soil thickness

Low fertility Orthic Anthrosols, Cab Medium fertility Orthic Anthrosols, and Fec Hydragric Anthrosols.

\section{Soil Aampling}

Sampling plots were designed with a grid-based sampling method and a total of 3,180 sampling grids $(150 \times 150 \mathrm{~m})$. The sampling sites were defined as the center of each sampling grid (Fig. 1). From March 2013 to January 2015, 2,755 soil profiles, consisting of 22,057 soil samples, were sampled in the designed sampling grids. A total of 425 designed sampling sites were located in places where sampling could not be carried out, such as in traffic throughways, on tractor roads, in residen- tial housing, industrial parks, streams, and so on. Each profile was divided into 12 soil horizons $(0-5 \mathrm{~cm}$, $5-10 \mathrm{~cm}, 10-15 \mathrm{~cm}, 15-20 \mathrm{~cm}, 20-30 \mathrm{~cm}, 30-40 \mathrm{~cm}$, $40-50 \mathrm{~cm}, 50-60 \mathrm{~cm}, 60-70 \mathrm{~cm}, 70-80 \mathrm{~cm}, 80-90 \mathrm{~cm}$, and $90-100 \mathrm{~cm}$ ) if the soil thickness was equal to or larger than $95 \mathrm{~cm}$. Otherwise, sampling was carried out to the actual depth. For instance, if a soil profile was $26 \mathrm{~cm}$ in depth, 5 soil samples were taken $(0-5 \mathrm{~cm}$, $5-10 \mathrm{~cm}, 10-15 \mathrm{~cm}, 15-20 \mathrm{~cm}$, and 20-26 cm); if a soil profile was $33 \mathrm{~cm}$ in thickness, 5 soil samples were taken (0-5 cm, 5-10 cm, 10-15 cm, 15-20 cm, and 20-30 cm).

Local information for each sampling point along with soil bulk density, soil thickness, rock coverage, and other indexes were measured at each point and recorded on

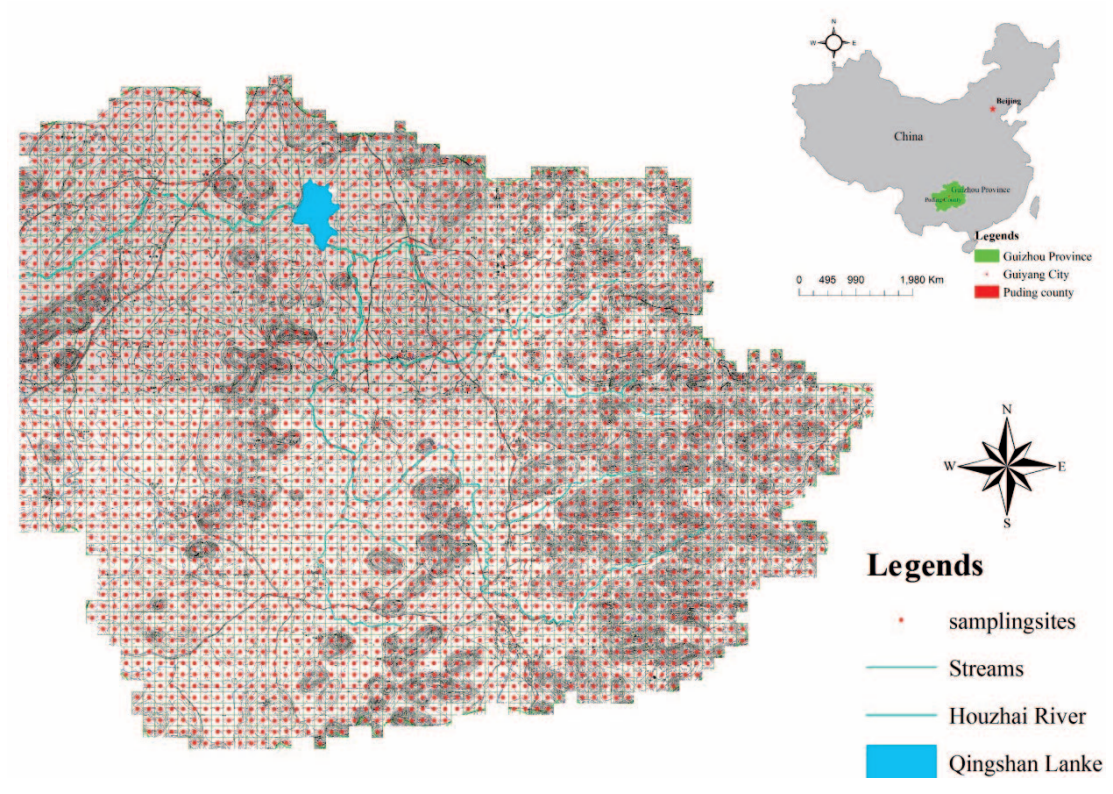

Fig. 1. Location of Houzhai River small watershed and the distribution of sample sites. 
the spot. The soil samples were air dried, ground, and prepared for the specimen as required by the laboratory; then the SOC content was tested and analyzed. The SOC was determined via the potassium dichromate method. The soil acreage was calculated using GIS technology and surveying in the field. The bulk density was measured layer by layer from the top to the bottom of the soil profile via a cutting-ring method. Soil thickness was recorded in accordance with the type of ecological niche with an iron stick that was 60 or $120 \mathrm{~cm}$ long, depending on the soil mass at different depths. The bare rock rate was surveyed with a line-transect method. Due to the complex landscape in a karst area, it would be more accurate but less operable if the line transect was too long. Therefore, the length of the line transect was set at $10 \mathrm{~m}$, and the grid cells with rock coverage were surveyed via tape measure.

\section{Calculations and Statistical Analysis}

Soil bulk density (SBD) was determined on the spot (cylindrical core method). For each layer of all soil profiles, $181.58 \mathrm{~cm}^{3}$ of soil was sampled with a cutting ring $(r=3.4 \mathrm{~cm}, h=5 \mathrm{~cm})$, and the fresh weight was obtained with a portable balance. Approximately 5 grams of soil from each layer were collected into an aluminum cup whose weight had been determined previously. $3 \mathrm{ml}$ of alcohol (95\%) was added and lit (repeated three times), and the weight was taken pre- and post-calcination. The SBD was calculated using the following equation:

$$
S B D=\frac{\left(W_{c r+s}-W_{c r}\right) \times\left(W_{p o s t}-W_{c u p}\right)}{\left(W_{p r e}-W_{c u p}\right) \times 181.58}
$$

...where SBD represents soil bulk density $\left(\mathrm{g} . \mathrm{cm}^{-3}\right), W_{c r}$ is the weight of the cutting ring $(\mathrm{g}), W_{c r+s}$ is the weight of the cutting ring with fresh soil $(\mathrm{g}), W_{\text {cup }}$ is the weight of the aluminum cup (g), $W_{\text {pre }}$ and $W_{\text {post }}$ are the pre- and postcalcination weights of the aluminum cup with soil (g), and 181.58 is the volume of the cutting ring $\left(\mathrm{cm}^{3}\right)$.

\section{Conventional Computation of SOC Storage and Formula Modification}

Considering the variety of soil types in the karst area, the soil type method was adopted. Because of the large variability of indexes, such as the SOC content, bulk density and soil thickness, SOC density (SOCD) was calculated layer by layer. The soil profile was divided into 12 layers. The SOC density in each layer was computed based on its corresponding SOC content, bulk density, and thickness. In addition, the spatial eigenvalue of the SOCD of the Houzhai River watershed in Puding was estimated based on the SOCD in each soil layer. Next, the SOCD and soil acreage of each soil type were used to determine SOC storage layer by layer, which was then used to determine the total SOC storage in the study area [16]. Thus, the equations for SOC density and storage can be defined as follows:

$$
\begin{aligned}
& \operatorname{SOCD}_{i, j}=C_{s o c_{i, j}} \times \rho_{i, j} \times T_{i, j} \times 10^{-2}, \\
& \mathrm{SOCS}=\sum_{j=1}^{m} \sum_{i=1}^{n} \operatorname{SOCD}_{i, j} \times S_{j} \times 10^{3}
\end{aligned}
$$

...where $\mathrm{SOC}_{i, j}$ is $\mathrm{SOC}$ density in the $i$ layer of soil $j\left(\mathrm{~kg} \cdot \mathrm{m}^{-2}\right), \mathrm{C}_{s o c} c_{i, j}$ is the SOC content in the $i$ layer of soil $j\left(\mathrm{~g}^{\mathrm{kg}} \mathrm{g}^{-1}\right), \rho_{i, j}$ is the soil bulk density in layer $i$ of soil $j\left(\mathrm{~g} \cdot \mathrm{cm}^{-3}\right), T_{i, j}$ is the soil thickness in layer $i$ of soil $j(\mathrm{~cm})$, $10^{-2}$ is the conversion coefficient, SOCS is the total storage of SOC in the study area (t), $S_{j}$ is the soil acreage of the soil $j\left(\mathrm{~km}^{2}\right)$, and $10^{3}$ is the unit conversion factor.

To minimize the difference between estimated and actual SOC storage, the error caused by rock coverage in the karst area was reduced by revising its bare rock rate. Equation (2) can be modified to generate Equation (3) as follows:

$$
\mathrm{SOCS}=\sum_{j=1}^{m} \sum_{i=1}^{n} S O C D_{i, j} \times S_{j} \times\left(1-\delta_{j}\right) \times\left(1-G_{j}\right) \times 10^{3}
$$

Table 2. Descriptive statistics of soil-related indexes.

\begin{tabular}{|c|c|c|c|c|c|c|c|c|c|c|c|}
\hline \multirow{4}{*}{ SOC } & Index & $\begin{array}{c}0-10 \\
\mathrm{~cm}\end{array}$ & $\begin{array}{c}10-20 \\
\mathrm{~cm}\end{array}$ & $\begin{array}{c}20-30 \\
\mathrm{~cm}\end{array}$ & $\begin{array}{c}30-40 \\
\mathrm{~cm}\end{array}$ & $\begin{array}{c}40-50 \\
\mathrm{~cm}\end{array}$ & $\begin{array}{c}50-60 \\
\mathrm{~cm}\end{array}$ & $\begin{array}{c}60-70 \\
\mathrm{~cm}\end{array}$ & $\begin{array}{c}70-80 \\
\mathrm{~cm}\end{array}$ & $\begin{array}{c}80-90 \\
\mathrm{~cm}\end{array}$ & $\begin{array}{c}90-100 \\
\mathrm{~cm}\end{array}$ \\
\hline & Standard Deviation $/(\mathrm{g} / \mathrm{kg})$ & 13.21 & 11.37 & 9.59 & 7.43 & 6.14 & 5.22 & 4.83 & 4.64 & 4.05 & 3.95 \\
& Variation coefficient $/ \%$ & 53.11 & 59.19 & 65.68 & 67.78 & 68.55 & 68.94 & 71.05 & 75.28 & 71.79 & 75.23 \\
& Mean $/\left(\mathrm{g} \cdot \mathrm{cm}^{-3}\right)$ & 1.17 & 1.22 & 1.29 & 1.34 & 1.38 & 1.39 & 1.39 & 1.41 & 1.39 & 1.38 \\
$\mathrm{SBD}$ & Standard Deviation $/\left(\mathrm{g} \cdot \mathrm{cm}^{-3}\right)$ & 0.21 & 0.21 & 0.22 & 0.22 & 0.22 & 0.20 & 0.19 & 0.56 & 0.20 & 0.22 \\
& Variation coefficient $/ \%$ & 17.95 & 17.21 & 17.05 & 16.42 & 15.94 & 14.39 & 13.67 & 39.72 & 14.39 & 15.94 \\
& Mean $/(\%)$ & 20.15 & 15.46 & 13.81 & 11.85 & 8.87 & 6.29 & 5.55 & 2.27 & 0 & 0 \\
$\mathrm{GC}$ & Standard Deviation $/(\%)$ & 7.85 & 7.71 & 7.36 & 6.14 & 5.96 & 5.51 & 0.63 & 0.13 & 0 & 0 \\
\cline { 2 - 12 } & Variation coefficient $/ \%$ & 38.96 & 49.87 & 53.29 & 51.81 & 67.19 & 87.60 & 11.35 & 5.73 & 0 & 0 \\
\hline
\end{tabular}


...where $\delta_{j}$ is the boulder content in the sampling area of soil $j(\%), G$ Tis the volume percentage of gravel that is larger than $2 \mathrm{~mm}$ of the soil $j$, and the other indexes are the same as those described for Equation (2).

After the second modification, Equation (3) can be used to estimate SOC storage (SOCS) in the karst area while considering the large variability of the related indexes being considered.

\section{Data Analysis}

First, with different levels of soil organic carbon density data values for quality control, the numerical calculations of the distribution with the 4-percentile method was used to determine the extreme limit and extreme limit values to calculate the maximum and minimum values, mean value, standard deviation, and coefficient of variation. Second, a spatial autocorrelation analysis was conducted using the semi-variance function variables, which must meet the normal distribution data of non-normal distribution; this will cause proportional effects on the variance function and reduce the estimation precision. If some characteristics of the potential performance were not obvious, then the normal distribution test was used; if the characteristics did not meet a normal distribution, the data were transformed.

Statistical analysis was performed using SPSS18.0 and Excel2007. Spatial information maps of soil thickness and rock exposure in the study region were used for ordinary kriging interpolation in ArcGIS 9.3 software.

\section{Results and Analysis}

\section{Statistical Analysis of Soil-Related Factors}

According to statistical analysis (Table 2) of SOC, SBD, and GC in the 2,755 soil profiles and 23,536 soil samples, the average SOC in the soil samples was 5.25-24.87 g. $\mathrm{kg}^{-1}$, the range was $19.62 \mathrm{~g} . \mathrm{kg}^{-1}$, and the maximum was 4.73 times as large as the minimum. In terms of stratification, the average SOC content at a depth of 0-10 cm was $24.87 \mathrm{~g} . \mathrm{kg}^{-1}$, followed by a depth of $10-20 \mathrm{~cm}$, which was $19.21 \mathrm{~g} \cdot \mathrm{kg}^{-1}$, and with the soil depth increasing, the average SOC decreased gradually, reaching its minimum of $5.25 \mathrm{~g} \cdot \mathrm{kg}^{-1}$ at a depth of $90-100 \mathrm{~cm}$. The SOC content varied greatly from layer to layer, and the variation coefficient changed in the range from 52.68 to $75.28 \%$, showing a moderately strong variation during $10-100 \%$; the average SBD was $1.17-1.41 \mathrm{~g} \cdot \mathrm{cm}^{-3}$, the maximum value was 1.21 times as large as the minimum value, and - with soil depth increasing - the SBD first increased then tended to be stable, reaching its maximum of $1.41 \mathrm{~g} . \mathrm{kg}^{-1}$ at a depth of 70-80 cm while reaching its minimum of 1.17 g. $\mathrm{kg}^{-1}$ at a depth of $0-10 \mathrm{~cm}$. The SOC content varied greatly from layer to layer, the variation coefficient changed in the range from 15.94 to $39.72 \%$, and showed a moderately weak variation during $10-50 \%$; the average GC ranged from 0 to $20.15 \%$ and decreased gradually until zero with soil depth increasing, reaching its maximum of $20.15 \%$ at a depth of $0-10 \mathrm{~cm}$ while reaching its minimum of zero at depths of 80-90 and 90-100 cm.

Table 3. Soil organic carbon density in different soil types $\left(\mathrm{kg} \cdot \mathrm{m}^{-2}\right)$.

\begin{tabular}{|c|c|c|c|c|c|c|c|c|c|}
\hline & \multicolumn{3}{|c|}{$0-20 \mathrm{~cm}$} & \multicolumn{3}{c|}{$0-30 \mathrm{~cm}$} & \multicolumn{3}{c|}{$0-100 \mathrm{~cm}$} \\
\hline Soil types & $\begin{array}{c}\text { Conven- } \\
\text { tional } \\
\text { method }\end{array}$ & $\begin{array}{c}\text { Optimi- } \\
\text { zation } \\
\text { method }\end{array}$ & $\begin{array}{c}\text { Reduced } \\
\text { value }\end{array}$ & $\begin{array}{c}\text { Conven- } \\
\text { tional } \\
\text { method }\end{array}$ & $\begin{array}{c}\text { Optimi- } \\
\text { zation } \\
\text { method }\end{array}$ & $\begin{array}{c}\text { Reduced } \\
\text { value }\end{array}$ & $\begin{array}{c}\text { Conven- } \\
\text { tional } \\
\text { method }\end{array}$ & $\begin{array}{c}\text { Optimi- } \\
\text { zation } \\
\text { method }\end{array}$ & $\begin{array}{c}\text { Reduced } \\
\text { value }\end{array}$ \\
\hline $\begin{array}{c}\text { Xan Udic } \\
\text { Fernalisols }\end{array}$ & 3.84 & 3.28 & 0.56 & 5.08 & 4.30 & 0.78 & 9.78 & 8.76 & 1.02 \\
\hline $\begin{array}{c}\text { Black } \\
\text { Lithomorphic } \\
\text { Isohumisols }\end{array}$ & 6.91 & 4.36 & 2.55 & 8.51 & 5.58 & 2.93 & 11.17 & 9.16 & 2.01 \\
\hline $\begin{array}{c}\text { Cab Udi Orthic } \\
\text { Entisols }\end{array}$ & 6.41 & 4.28 & 2.13 & 8.20 & 5.54 & 2.66 & 11.14 & 8.69 & 2.45 \\
\hline $\begin{array}{c}\text { Cab High } \\
\text { fertility Orthic } \\
\text { Anthrosols }\end{array}$ & 5.55 & 4.89 & 0.66 & 7.51 & 6.64 & 0.87 & 12.60 & 10.58 & 2.02 \\
\hline $\begin{array}{c}\text { Cab Low } \\
\text { fertility Orthic } \\
\text { Anthrosols }\end{array}$ & 5.32 & 3.94 & 1.38 & 7.01 & 5.18 & 1.83 & 10.53 & 8.86 & 1.67 \\
\hline $\begin{array}{c}\text { Cab Low } \\
\text { fertility Orthic } \\
\text { Anthrosols }\end{array}$ & 6.13 & 5.74 & 0.39 & 8.09 & 7.65 & 0.44 & 14.19 & 11.89 & 2.3 \\
\hline $\begin{array}{c}\text { Fec Hydragric } \\
\text { Anthrosols }\end{array}$ & 5.43 & 5.01 & 0.42 & 7.15 & 6.56 & 0.59 & 11.80 & 10.68 & 1.12 \\
\hline \begin{tabular}{c} 
Total \\
\hline
\end{tabular} & 39.59 & 31.5 & 8.09 & 51.55 & 41.45 & 10.1 & 81.21 & 68.62 & 12.59 \\
\hline
\end{tabular}


Table 4. Soil organic carbon density under different utilization patterns $\left(\mathrm{kg} \cdot \mathrm{m}^{2}\right)$.

\begin{tabular}{|c|c|c|c|c|c|c|c|c|c|}
\hline & \multicolumn{3}{|c|}{$0-20 \mathrm{~cm}$} & \multicolumn{3}{c|}{$0-30 \mathrm{~cm}$} & \multicolumn{3}{c|}{$0-100 \mathrm{~cm}$} \\
\hline Land types & $\begin{array}{c}\text { Conven- } \\
\text { tional } \\
\text { method }\end{array}$ & $\begin{array}{c}\text { Optimi- } \\
\text { zation } \\
\text { method }\end{array}$ & $\begin{array}{c}\text { Reduced } \\
\text { value }\end{array}$ & $\begin{array}{c}\text { Conven- } \\
\text { tional } \\
\text { method }\end{array}$ & $\begin{array}{c}\text { Optimi- } \\
\text { zation } \\
\text { method }\end{array}$ & $\begin{array}{c}\text { Reduced } \\
\text { value }\end{array}$ & $\begin{array}{c}\text { Conven- } \\
\text { tional } \\
\text { method }\end{array}$ & $\begin{array}{c}\text { Optimi- } \\
\text { zation } \\
\text { method }\end{array}$ & $\begin{array}{c}\text { Reduced } \\
\text { value }\end{array}$ \\
\hline Woodland & 6.15 & 4.45 & 1.70 & 7.74 & 5.56 & 2.18 & 10.52 & 7.49 & 3.03 \\
\hline Shrub grass & 7.15 & 4.38 & 2.77 & 8.81 & 5.45 & 3.36 & 10.90 & 7.18 & 3.72 \\
\hline Paddy field & 5.71 & 5.09 & 0.62 & 7.53 & 6.73 & 0.8 & 12.92 & 10.82 & 2.1 \\
\hline Dry land & 4.70 & 4.04 & 0.66 & 6.19 & 5.34 & 0.85 & 10.32 & 8.12 & 2.2 \\
\hline Wasteland & 6.56 & 3.97 & 2.59 & 8.27 & 5.11 & 3.16 & 10.85 & 6.71 & 4.14 \\
\hline Total & 30.27 & 21.93 & 8.34 & 38.54 & 28.19 & 10.35 & 55.51 & 40.32 & 15.19 \\
\hline
\end{tabular}

With rock coverage being counted, the soil coverage is overrated. Therefore, the value of soil acreage should be revised by taking rate of rock acreage into consideration. The rate of rock coverage is very different in different soil genera. The mean rate of rock coverage in the Rendzina area is abut $43.34 \%$, which is the highest; while it is $29.22 \%$, the lowest, in large loam of tillage soil. There is little rock exposure in three major tillage areas (yellow clay, large mud field loam, and yellow clayey soil), so the rate of rock acreage in these areas is very low.

\section{Soil Organic Carbon Density}

\section{SOCD in Different Types of Soil}

As can be seen in Table 3, there was a difference in SOCD in the 7 types of soil: conventional calculation suggested that the SOCD at a depth of $20 \mathrm{~cm}$ was 3.84-6.91 kg.m ${ }^{-2}$, and decreased to $3.28-5.74 \mathrm{~kg} . \mathrm{m}^{-2}$ upon the optimization of $\mathrm{RC}$ and $\mathrm{GC}$, showing a gross difference of $8.09 \mathrm{~kg} . \mathrm{m}^{-2}$ before and after optimization. The soil types in the order of SOCD decrease are: Black Lithomorphic Isohumisols > Cab Udi Orthic Entisols $>$ Cab Low fertility Orthic Anthrosols > Cab High fertility Orthic Anthrosols $>$ Xan Udic Fernalisols $>$ Fec Hydragric Anthrosols $>$ Cab Low fertility Orthic Anthrosols; the conventional calculation suggested that SOCD at a depth of $30 \mathrm{~cm}$ was $5.08-8.51 \mathrm{~kg} . \mathrm{m}^{-2}$, and decreased to $4.30-7.65 \mathrm{~kg} \cdot \mathrm{m}^{-2}$ upon the optimization of $\mathrm{RC}$ and $\mathrm{GC}$, showing a gross difference of $10.10 \mathrm{~kg} / \mathrm{m}^{2}$ before and after optimization. The soil types in the order of SOCD decrease are: Black Lithomorphic Isohumisols $>$ Cab Udi Orthic Entisols > Cab Low fertility Orthic Anthrosols $>$ Cab High fertility Orthic Anthrosols $>$ Xan Udic Fernalisols $>$ Fec Hydragric Anthrosols $>\mathrm{Cab}$ Medium fertility Orthic Anthrosols; the conventional calculation suggested that SOCD at a depth of $100 \mathrm{~cm}$ was $9.78-14.19 \mathrm{~kg} \cdot \mathrm{m}^{-2}$, and decreased to $8.69-11.89 \mathrm{~kg} \cdot \mathrm{m}^{-2}$ upon the optimization of $\mathrm{RC}$ and $\mathrm{GC}$, showing a gross difference of $12.59 \mathrm{~kg} \cdot \mathrm{m}^{-2}$ before and after optimization. The soil types in the order of SOCD decrease are: Cab Udi Orthic Entisols $>$ Cab Low fertility Orthic Anthrosols $>\mathrm{Cab}$ High fertility Orthic Anthrosols $>$ Black Lithomorphic
Isohumisols $>$ Cab Low fertility Orthic Anthrosols $>$ Fec Hydragric Anthrosols > Xan Udic Fernalisols.

\section{SOCD under Different Land Utilization Types}

See Table 4 for the average SOCD under the main land utilization types in Houzhai Basin. Due to the difference in SOC content between different land utilization types, there was also a difference in SOCD. In terms of vertical distribution, the SOCD under 5 land utilization types appeared as $100 \mathrm{~cm}>30 \mathrm{~cm}>20$ $\mathrm{cm}$. In terms of horizontal distribution, due to the high SOC content and SBD in paddy field, the SOC in each layer of soil was higher than that in the corresponding soil layer in forestland, grassland, unused land, and dry land. The conventional calculation suggested that SOCD at a depth of $20 \mathrm{~cm}$ was $5.71-7.15 \mathrm{~kg} . \mathrm{m}^{-2}$, and decreased to $3.97-5.09 \mathrm{~kg} . \mathrm{m}^{-2}$ upon the optimization of RC and GC, showing a gross difference of $8.34 \mathrm{~kg} \cdot \mathrm{m}^{-2}$ before and after optimization; the conventional calculation suggested that SOCD at a depth of $30 \mathrm{~cm}$ was $7.74-8.81 \mathrm{~kg} \cdot \mathrm{m}^{-2}$, and decreased to $5.11-6.73 \mathrm{~kg} . \mathrm{m}^{-2}$ upon the optimization of RC and GC, showing a gross difference of $10.35 \mathrm{~kg} \cdot \mathrm{m}^{-2}$ before and after optimization; the conventional calculation suggested that the SOCD at a depth of $1,000 \mathrm{~cm}$ was 10.32-12.92 kg.m ${ }^{-2}$, and decreased to $6.71-10.82 \mathrm{~kg} \cdot \mathrm{m}^{-2}$ upon the optimization of $\mathrm{RC}$ and $\mathrm{GC}$, showing a gross difference of $15.19 \mathrm{~kg} \cdot \mathrm{m}^{-2}$ before and after optimization. Soil types in the order of SOC decrease at different soil depths as: shrubby grassland $>$ wasteland $>$ forest land $>$ dry land $>$ paddy field.

\section{Difference in SOCD in Different Slope Aspects}

See Table 5 for the SOCD in different slope aspects in the Houzhai Basin. Due to the difference in SOCC in different slope aspects, there was a difference in SOCD. In terms of vertical distribution, the SOCD in 5 slope aspects at different soil depths appeared as $100 \mathrm{~cm}>30$ $\mathrm{cm}>20 \mathrm{~cm}$. In terms of horizontal distribution, since there was high SOC and SBD in the soil without slope, the SOCD in all the layers of soil was higher than that in the corresponding layer in other types of soil. The conventional 
Table 5. Soil organic carbon density under different slopes $\left(\mathrm{kg} \cdot \mathrm{m}^{-2}\right)$.

\begin{tabular}{|c|c|c|c|c|c|c|c|c|c|}
\hline & \multicolumn{4}{|c|}{$0-20 \mathrm{~cm}$} & \multicolumn{3}{c|}{$0-30 \mathrm{~cm}$} & \multicolumn{3}{c|}{$0-100 \mathrm{~cm}$} \\
\hline Slope types & $\begin{array}{c}\text { Conven- } \\
\text { tional } \\
\text { method }\end{array}$ & $\begin{array}{c}\text { Optimization } \\
\text { method }\end{array}$ & $\begin{array}{c}\text { Reduced } \\
\text { value }\end{array}$ & $\begin{array}{c}\text { Conven- } \\
\text { tional } \\
\text { method }\end{array}$ & $\begin{array}{c}\text { Optimization } \\
\text { method }\end{array}$ & $\begin{array}{c}\text { Reduced } \\
\text { value }\end{array}$ & $\begin{array}{c}\text { Conven- } \\
\text { tional } \\
\text { method }\end{array}$ & $\begin{array}{c}\text { Optimization } \\
\text { method }\end{array}$ & $\begin{array}{c}\text { Reduced } \\
\text { value }\end{array}$ \\
\hline East & 5.91 & 4.11 & 1.8 & 7.42 & 5.20 & 2.22 & 10.39 & 7.58 & 2.81 \\
\hline South & 6.20 & 4.18 & 2.02 & 7.61 & 5.20 & 2.41 & 9.95 & 7.05 & 2.9 \\
\hline West & 4.69 & 4.01 & 0.68 & 5.18 & 5.10 & 0.08 & 7.69 & 7.37 & 0.32 \\
\hline North & 5.36 & 4.38 & 0.98 & 6.94 & 5.73 & 1.21 & 9.81 & 8.28 & 1.53 \\
\hline No slope & 4.49 & 4.48 & 0.01 & 5.91 & 5.89 & 0.02 & 10.10 & 9.93 & 0.17 \\
\hline Total & 26.65 & 21.16 & 5.49 & 33.06 & 27.12 & 5.94 & 47.94 & 40.21 & 7.73 \\
\hline
\end{tabular}

calculation suggested that SOCD at a depth of $20 \mathrm{~cm}$ was 4.49-6.20 kg.m ${ }^{-2}$, and decreased to 4.01-4.48 kg.m ${ }^{-2}$ upon the optimization of $\mathrm{RC}$ and $\mathrm{GC}$, showing a gross difference of $5.49 \mathrm{~kg} \cdot \mathrm{m}^{-2}$ before and after optimization; the conventional calculation suggested that SOCD at a depth of $30 \mathrm{~cm}$ was $4.49-6.20 \mathrm{~kg} . \mathrm{m}^{-2}$, and decreased to 5.20-5.89 kg.m $\mathrm{m}^{-2}$ upon the optimization of RC and GC, showing a gross difference of $5.94 \mathrm{~kg} . \mathrm{m}^{-2}$ before and after optimization; the conventional calculation suggested that SOCD at a depth of $100 \mathrm{~cm}$ was $7.69-10.39 \mathrm{~kg} \cdot \mathrm{m}^{-2}$, and decreased to $7.05-9.93 \mathrm{~kg} . \mathrm{m}^{-2}$ upon the optimization of RC and GC, showing a gross difference of $7.73 \mathrm{~kg} . \mathrm{m}^{-2}$ before and after optimization. The slope aspects in the order of SOCD increase are: south slope $>$ east slope $>$ north slope $>$ west slope $>$ no slope.

\section{Comparison of SOC Storage by Different} Estimation Methods

\section{Soil Type Method}

The soil type method was used to estimate the SOCS in Houzhai Basin (Table 5). As can be seen in Table 6, RC showed some effect on SOCS in Houzhai Basin. According

Table 6. Estimation and optimization of soil organic carbon storage by soil type $\left(10^{6} \mathrm{~kg}\right)$.

\begin{tabular}{|c|c|c|c|c|c|c|c|c|c|}
\hline $\begin{array}{c}\text { Soil } \\
\text { depths }\end{array}$ & Index & $\begin{array}{l}\text { Xan Udic } \\
\text { Fernalisols }\end{array}$ & $\begin{array}{c}\text { Black } \\
\text { Lithomorphic } \\
\text { Isohumisols }\end{array}$ & $\begin{array}{l}\text { Cab Udi } \\
\text { Orthic } \\
\text { Entisols }\end{array}$ & $\begin{array}{c}\text { Cab High } \\
\text { fertility Orthic } \\
\text { Anthrosols }\end{array}$ & $\begin{array}{c}\text { Cab Low fer- } \\
\text { tility Orthic } \\
\text { Anthrosols }\end{array}$ & $\begin{array}{c}\text { Cab Medium } \\
\text { fertility Orthic } \\
\text { Anthrosols } \\
\end{array}$ & $\begin{array}{c}\text { Fec } \\
\text { Hydragric } \\
\text { Anthrosols }\end{array}$ & Total \\
\hline \multirow{4}{*}{$\begin{array}{c}0-20 \\
\mathrm{~cm}\end{array}$} & $\begin{array}{l}\text { Conven- } \\
\text { tional value }\end{array}$ & 60.98 & 78.64 & 67.31 & 18.81 & 14.10 & 180.65 & 2.61 & 423.1 \\
\hline & $\begin{array}{l}\text { Optimal } \\
\text { value }\end{array}$ & 52.09 & 49.62 & 44.94 & 16.58 & 10.44 & 165.75 & 2.40 & 341.82 \\
\hline & $\begin{array}{l}\text { Reduce } \\
\text { amount }\end{array}$ & 8.89 & 29.02 & 22.37 & 2.24 & 3.66 & 14.90 & 0.20 & 81.29 \\
\hline & Error rate & 14.58 & 36.90 & 33.23 & 11.91 & 25.96 & 8.25 & 7.66 & 19.21 \\
\hline \multirow{4}{*}{$\begin{array}{c}0-30 \\
\mathrm{~cm}\end{array}$} & $\begin{array}{l}\text { Conven- } \\
\text { tional value }\end{array}$ & 80.67 & 96.84 & 86.10 & 25.46 & 18.58 & 236.78 & 3.43 & 547.86 \\
\hline & $\begin{array}{l}\text { Optimal } \\
\text { value }\end{array}$ & 68.28 & 63.50 & 58.17 & 22.51 & 13.73 & 219.95 & 3.15 & 449.29 \\
\hline & $\begin{array}{l}\text { Reduce } \\
\text { amount }\end{array}$ & 12.39 & 33.34 & 27.93 & 2.95 & 4.85 & 16.83 & 0.28 & 98.56 \\
\hline & Error rate & 15.36 & 34.43 & 32.44 & 11.59 & 26.10 & 7.11 & 8.16 & 17.99 \\
\hline \multirow{4}{*}{$\begin{array}{c}0-100 \\
\mathrm{~cm}\end{array}$} & $\begin{array}{l}\text { Conven- } \\
\text { tional value }\end{array}$ & 155.31 & 127.11 & 116.97 & 42.71 & 27.90 & 407.9 & 5.66 & 883.56 \\
\hline & $\begin{array}{l}\text { Optimal } \\
\text { value }\end{array}$ & 139.11 & 104.24 & 91.25 & 35.87 & 23.48 & 339.27 & 5.13 & 738.35 \\
\hline & $\begin{array}{l}\text { Reduce } \\
\text { amount }\end{array}$ & 16.20 & 22.87 & 25.73 & 6.85 & 4.43 & 68.63 & 0.54 & 145.25 \\
\hline & Error rate & 10.43 & 17.99 & 22.00 & 16.04 & 15.88 & 16.83 & 9.54 & 16.43 \\
\hline
\end{tabular}


Table 7. Estimation and optimization of soil organic carbon storage by land use $\left(10^{6} \mathrm{~kg}\right)$.

\begin{tabular}{|c|c|c|c|c|c|c|c|}
\hline Soil depths & Index & Woodland & Shrub grass & Paddy field & Dry land & Wasteland & Total \\
\hline \multirow{4}{*}{$0-20 \mathrm{~cm}$} & Conventional value & 20.05 & 40.68 & 99.81 & 107.40 & 163.34 & 431.28 \\
\cline { 2 - 8 } & Optimal value & 14.51 & 24.92 & 88.97 & 92.31 & 98.85 & 319.56 \\
\cline { 2 - 8 } & Reduce amount & 5.54 & 15.76 & 10.84 & 15.08 & 64.49 & 111.71 \\
\cline { 2 - 8 } & Error rate & 27.63 & 38.74 & 10.86 & 14.04 & 39.48 & 25.90 \\
\hline \multirow{3}{*}{$0-30 \mathrm{~cm}$} & Conventional value & 25.23 & 50.13 & 131.62 & 141.44 & 205.92 & 554.34 \\
\cline { 2 - 9 } & Optimal value & 18.13 & 31.01 & 117.64 & 122.02 & 127.24 & 416.04 \\
\cline { 2 - 9 } & Reduce amount & 7.11 & 19.12 & 13.98 & 19.42 & 78.68 & 138.31 \\
\cline { 2 - 8 } & Error rate & 28.18 & 38.14 & 10.62 & 13.73 & 38.21 & 24.95 \\
\hline \multirow{3}{*}{$0-100 \mathrm{~cm}$} & Conventional value & 34.30 & 62.02 & 225.84 & 235.81 & 270.17 & 828.14 \\
\cline { 2 - 8 } & Optimal value & 24.42 & 40.85 & 189.13 & 185.54 & 167.08 & 607.02 \\
\cline { 2 - 8 } & Reduce amount & 9.88 & 21.17 & 36.71 & 50.27 & 103.09 & 221.12 \\
\cline { 2 - 8 } & Error rate & 28.80 & 34.13 & 16.25 & 21.32 & 38.16 & 26.70 \\
\hline
\end{tabular}

to the estimation in the traditional mode, SOCS was $423.1 \times 10^{6} \mathrm{~kg}$ at a depth of $20 \mathrm{~cm}$, while it was $341.82 \times 10^{6} \mathrm{~kg}$ in the optimization mode; at a depth of $100 \mathrm{~cm}$, the SOCS was $883.56 \times 10^{6} \mathrm{~kg}$ in the traditional mode and $738.35 \times 10^{6}$ $\mathrm{kg}$ in the optimization mode, seeing a decrease of $16.43 \%$ before and after optimization. The soil depths in the order of decrease are: $100 \mathrm{~cm}>30 \mathrm{~cm}>20 \mathrm{~cm}$. As RC and GC were optimized for SOC storage in Houzhai Basin by the soil type method, different rates of estimation errors were caused among different types of soil. The estimation error rate was less than $10 \%$ in the topsoil $(0-20 \mathrm{~cm})$ of $\mathrm{Cab}$ Medium fertility Orthic Anthrosols and Fec Hydragric Anthrosols due to the insignificant effect of RC and GC, greater than 30\% in Black Lithomorphic Isohumisols and Cab Udi Orthic Entisols, and not greater than 30\% in all the remaining types of soil. Among the entire soil profiles $(0-100 \mathrm{~cm})$, the estimation error rate of Cab Udi Orthic Entisols was highest, equal to $22.00 \%$, while that of Fec Hydragric Anthrosols was lowest, equal to $9.54 \%$, except Cab Medium fertility Orthic Anthrosols, the estimation error rate of all other soil types decreased gradually with increasing soil depth, and RC showed a great effect on SOC storage in Houzhai Basin.

\section{Land Utilization Type Method}

The land utilization type method was used to estimate SOC storage in Houzhai Basin in both traditional and optimization modes (Table 7). RC showed a certain effect on SOC storage in Houzhai Basin under different land utilization types. At a depth of $20 \mathrm{~cm}$ SOC storage was $431.28 \mathrm{t}$ by the conventional estimation, and $319.56 \times 10^{6}$ $\mathrm{kg}$ after optimization, with an estimation error rate of $25.90 \%$; at a depth of $100 \mathrm{~cm}$ SOC storage was $828.14 \times 10^{6}$ $\mathrm{kg}$ by the conventional estimation, and $607.02 \times 10^{6} \mathrm{~kg}$ after optimization with an estimation error rate of $25.90 \%$, $24.95 \%$, and $26.70 \%$, respectively, at different soil depths.
There was a difference in estimation error rate under different land utilization types: the estimation error rate was $10.86 \%$ in the topsoil $(0-20 \mathrm{~cm})$ of paddy field due to the insignificant effect of $\mathrm{RC}$ and $\mathrm{GC}$, greater than $30 \%$ under the land utilization types wasteland and bush forest, while it was less than $30 \%$ under all other types. In terms of different soil depths, the estimation error rate
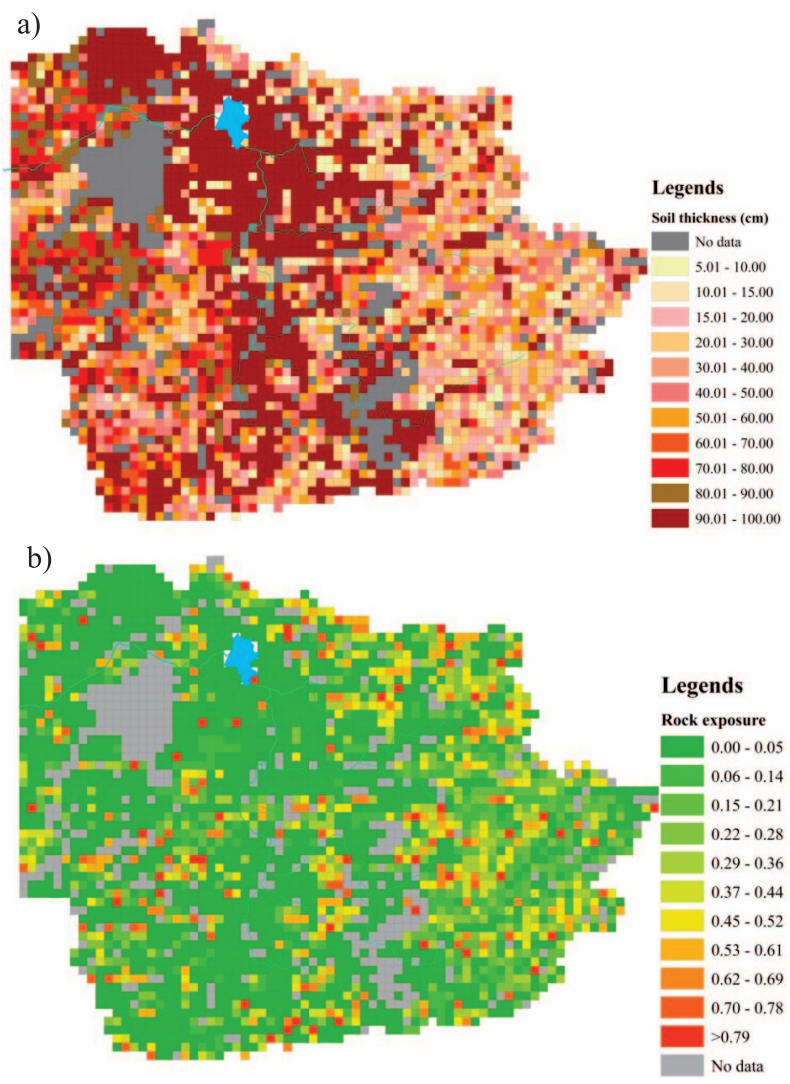

Fig. 2. Spatial information of soil thickness and rock exposure in the study region. 
Table 8. Estimation and optimization of soil organic carbon storage by slope method $\left(10^{6} \mathrm{~kg}\right)$.

\begin{tabular}{|c|c|c|c|c|c|c|c|}
\hline Soil depths & Index & East & South & West & North & No slope & Total \\
\hline \multirow{4}{*}{$0-20 \mathrm{~cm}$} & Conventional value & 49.82 & 62.56 & 58.20 & 89.03 & 119.57 & 379.18 \\
\cline { 2 - 8 } & Optimal value & 34.65 & 42.18 & 49.76 & 72.75 & 119.30 & 318.64 \\
\cline { 2 - 9 } & Reduce amount & 15.17 & 20.38 & 8.44 & 16.28 & 0.27 & 60.54 \\
\cline { 2 - 9 } & Error rate & 30.45 & 32.58 & 14.50 & 18.29 & 0.23 & 15.97 \\
\hline \multirow{3}{*}{$0-30 \mathrm{~cm}$} & Conventional value & 62.55 & 76.78 & 64.28 & 115.27 & 157.38 & 476.26 \\
\cline { 2 - 9 } & Optimal value & 43.84 & 52.47 & 63.29 & 95.18 & 156.85 & 411.63 \\
\cline { 2 - 9 } & Reduce amount & 18.71 & 24.32 & 0.99 & 20.10 & 0.53 & 64.65 \\
\hline \multirow{3}{*}{$0-100 \mathrm{~cm}$} & Error rate & 29.91 & 31.67 & 1.54 & 17.44 & 0.34 & 13.57 \\
\cline { 2 - 9 } & Conventional value & 87.59 & 100.40 & 95.43 & 162.94 & 268.96 & 715.32 \\
\cline { 2 - 8 } & Optimal value & 63.90 & 71.13 & 91.46 & 137.53 & 264.44 & 628.46 \\
\cline { 2 - 8 } & Reduce amount & 23.69 & 29.26 & 3.97 & 25.41 & 4.53 & 86.86 \\
\hline
\end{tabular}

decreased gradually with the soil depth increasing under various land utilization types, all appearing as wasteland $>$ bush forest $>$ forestland $>$ dry land $>$ paddy field. RC showed a great effect on SOCS in Houzhai Basin.

\section{Slope Aspect Method}

The slope aspect method was used to estimate the SOCS in Houzhai Basin in both traditional mode and optimization mode. See Table 8 for the results. As can be seen from Table 6, RC showed some effect on SOCS under different slope aspects in Houzhai Basin. At a depth of 0-20 cm, 0-30 cm, and 0-100 cm, the SOCS was shown to be $379.18 \times 10^{6} \mathrm{~kg}$ and $476.26 \times 10^{6} \mathrm{~kg}$ and $715.32 \times 10^{6} \mathrm{~kg}$, respectively by conventional estimation, and $318.64 \times 10^{6}$ $\mathrm{kg}, 411.63 \times 10^{6} \mathrm{~kg}$, and $628.46 \times 10^{6} \mathrm{~kg}$ respectively after optimization. There was a difference in estimation error rate between different slope aspects, and the estimation error rate of SOCS in non-sloping topsoil $(0-20 \mathrm{~cm})$ due to the little effect of RC; the estimation error rate of SOCS in the east slope and south slope was greater than $30 \%$, while that in the rest slopes was not greater than $20.00 \%$.

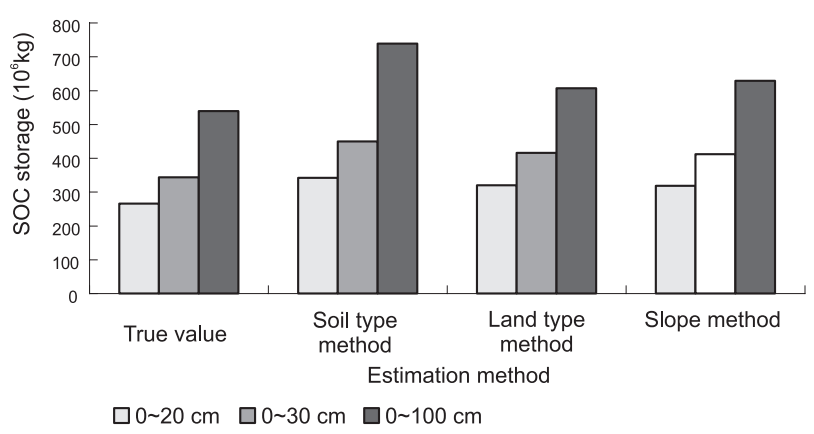

Fig. 3. Comparison of organic carbon storage under different estimation methods.
In terms of different soil depths, the estimation error rate decreased gradually with the soil depth increasing in different slope aspects, all appearing as that south slope $>$ east slope $>$ west slope $>$ non-slope. RC showed a great effect on the SOCS in different slope aspects.

\section{Comparison of SOCS by Different Estimation Methods}

For the same area, different estimation methods would produce different estimation results (Fig. 3). The soil type method estimated the storage to be large, the land utilization type method was almost on par with the slope aspect method at a depth of 0-20 cm and 0-30 cm, the soil type method estimated the SOCS to be $738.35 \times 10^{6} \mathrm{~kg}$ at a depth of $100 \mathrm{~cm}$, the land utilization type method was estimated to be $607.02 \times 10^{6} \mathrm{~kg}$, and the slope aspect method was estimated at $628.46 \times 10^{6} \mathrm{~kg}$. The SOCS was calculated layer by layer at each sampling point. The SOCD at various layers was calculated one by one in accordance with the SOCC, SBD, and soil thickness in the corresponding layers, and then the SOCS in all soil profiles were added together, ascertaining the gross SOCS at all soil depths in the study area. After that, soil depth, RC, and soil block area in each soil profile were investigated in detail when the regional SOCS was estimated by the soil profile SOCS summation method, which could reveal the real SOCS in the soil, so it was identified as an accurately estimated SOCS in the study area. In detail, the SOCS was $265.46 \times 10^{6} \mathrm{~kg}$ at a depth of $0-20 \mathrm{~cm}, 343.49 \times 10^{6} \mathrm{~kg}$ at a depth of $0-30 \mathrm{~cm}$, and $539.17 \times 10^{6} \mathrm{~kg}$ at a depth of $0-100 \mathrm{~cm}$. According to the comparison of the three estimation methods with the real SOCS, the slope aspect method achieved the best effect in the topsoil $(0-20 \mathrm{~cm}, 0-30 \mathrm{~cm})$, while the soil utilization type method achieved the best effect in the entire profile $(0-100 \mathrm{~cm})$. 


\section{Discussion}

\section{Impacts of Using Different Methods to Estimate Soil Organic Carbon Storage}

Scholars have performed numerous estimates of soil carbon storage. The main estimation methods include those based on soil taxonomy, modeling, carbon fitting, GIS estimation, vegetation types, ecosystem types and Holdridge life zones, climate parameters, correlation statistics, and statistical estimation [17]. These methods are used to estimate the organic carbon stock of large non-karst areas from various perspectives and based on various considerations [18]. However, to estimate soil organic carbon storage in small drainage basins in karst areas, it is necessary to consider the local scale and spatial heterogeneity [19]. Thus, the choice of an estimation method is critical. The spatial heterogeneity of karst areas is so different from the relative homogeneity of non-karst areas that the common estimation methods used in nonkarst areas cannot be applied directly to karst areas. Soil conditions in karst areas are characterized by extensive bedrock exposure, small soil stocks, discontinuous soil distributions, and complex and diverse micro-landscapes. When estimating the organic carbon storage in karst areas, scholars typically do not take into account the effects of gravel content and the extent of rock exposure on the soil organic carbon storage. Thus, to estimate the soil organic carbon storage in karst areas it is necessary to calibrate the extent of rock exposure and gravel content. Spatial variations in karst areas are both horizontal and vertical. Soluble carbonate bedrock forms a complex and diverse geomorphology and landscapes and spatially variable lithology, soil, and land use [20]. Therefore, this study compared the following methods of estimating organic carbon storage: soil taxonomy, land use, and slope aspect methods. Spatial heterogeneity in the Houzhai River basin is extremely high and is characterized by complex horizontal and vertical 2-D structures [21]. Horizontally, peaks, depressions, and bedrock exposure lead to a patchy soil cover and diverse soil types and land use types. Vertically, the soil thicknesses vary, which leads to significant differences between layers of a given soil type [22]. Thus, when applying soil taxonomy to estimate soil organic carbon storage in karst areas, one must consider the 2-D spatial heterogeneity of the soil. According to the soil classification, the Houzhai River basin contains three major types of lime soil, three of yellow soil, and three of paddy soil. According to the soil properties, the basin contains nine types that display great spatial variations in organic carbon content. Thus, the soil organic carbon storage can be estimated from the weighted average of soil property types. In other words, it can be estimated using the soil taxonomy method, and the soil types are identical to the soil layers.

According the mechanism of soil organic carbon fixation, the amount of external organic matter added to the soil directly impacts soil organic carbon fixation and storage. The external sources of organic matter are controlled by the soil cover, i.e., land use. The Houzhai River basin contains multiple land uses and can generally be divided into five types with great spatial variations in organic carbon content. Thus, the soil organic carbon storage can be estimated from the weighted average of land use. Due to great spatial heterogeneity, the estimates developed for the Houzhai River basin differ to some degree depending on whether they were developed using the vertical stratification + horizontal classification method, the land use method, or the slope aspect method. The slope method was used to estimate organic carbon storage in the surface soil, and the land use method yielded the best estimates at a depth of $100 \mathrm{~cm}$.

\section{Effects of Rock Exposure Extent and Gravel Content on Soil Organic Carbon Storage}

The plateau karst small drainage basins are underlain by limestone and dolomite. The bedrock is widely exposed, and the micro-habitats are diverse [23]. Large amounts of weathering residue accumulate in rock fissures and are intruded upon by plant roots [24]. Scattered patches of thin soil are developed on the bedrock. The average thickness of soil on the slopes is only 4-9 cm. Therefore, knowing the soil organic carbon storage in the various soils in the karst areas is the basis for assessing the regional soil carbon fixation [25]. The accuracy of the soil organic carbon storage estimation is related not only to the estimation method but also to the accuracy of indicators, including SOC content, soil bulk density, soil thickness, and the lateral extent of soil cover. When estimating karst carbon storage and density, one should consider the extent of rock exposure, soil thickness, and gravel content - all of which can greatly affect the estimation error. All these indicators are important factors in determining soil organic carbon storage [26]. Additionally, the areal extent of soil cover in the karst regions is a function of the extent of exposed rock, and the gravel content affects soil bulk density and soil thickness [27]. Thus, the surveyed soil covered area is larger than the actual area of soil cover. Because of the unique conditions in the karst areas, the methods used to estimate carbon storage and density in non-karst areas are not suitable, and it is necessary to calibrate the method to account for the percentage of rock exposure and gravel content to obtain accurate estimates.

The 2-D spatial heterogeneity in the karst areas leads to variability of indicators, including soil organic carbon content, gravel content, and rock exposure percentage all of which in turn control soil organic carbon storage [28]. We calibrated the soil organic carbon storage at various depths against the rock exposure percentage and gravel content. The calibrated error based on rock exposure percentage is $5-30 \%$ between soil depths of $0-20 \mathrm{~cm}$ and $9-30 \%$ between soil depths of 0 and $100 \mathrm{~m}$, indicating that the rock exposure percentage and gravel content significantly impact soil organic carbon storage in the karst areas. Thus, when estimating soil organic carbon storage in the karst areas it is important to first consider the rock exposure percentage and gravel content. In addition, 
the estimation method based on the calibration of rock exposure and gravel content yields more-accurate results in the sampled areas than do the conventional estimation methods. The calibrated method is particularly well suited to estimating organic carbon storage in the surficial slope soil in high-elevation rocky karst regions, whereas the conventional estimation methods are not. According to the field survey, the average rock exposure percentage among various niche soil types in the sampled soil patches is $12.9-31.0 \%$, and the soil distribution is patchy. In contrast, the conventional methods assume the presence of laterally continuous soils, leading to overestimation of the soil area and large errors. This finding suggests that the estimation of the organic carbon storage in the karst areas using conventional methods leads to large errors.

\section{Conclusions}

The average organic carbon content in the soil samples from the small karst drainage basins is 5.25$24.87 \mathrm{~g} . \mathrm{kg}^{-1}$. The soil organic carbon content is highest in the $0-10-\mathrm{cm}$ soil interval (i.e., $24.87{\mathrm{~g} . \mathrm{kg}^{-1}}^{-1}$ ), and decreases gradually with depth. The average soil bulk density is $1.17-1.41{\mathrm{~g} . \mathrm{cm}^{-3}}^{-3}$ and the maximum density is 1.21 times the minimum. With increasing depth, the soil bulk density increases and then stabilizes. The average gravel content is $0-20.15 \%$. With increasing depth, the gravel content gradually decreases to 0 : it is greatest in the $0-10-\mathrm{cm}$ interval (i.e., $20.15 \%$ ), and is least in the $80-90$ and $90-100-\mathrm{cm}$ intervals, where the gravel content is 0 .

Based on the calibration of the areal rock exposure percentage and the gravel content, soil organic carbon storage was estimated using soil taxonomy, land use, and slope methods. Organic carbon storage is $318.64 \times 10^{6}$ $341.82 \times 10^{6} \mathrm{~kg}$ at $0-20 \mathrm{~cm}, 411.63 \times 10^{6-449.29 \times 10^{6} \mathrm{~kg} \text { at }}$ $0-30 \mathrm{~cm}$ and $607.02 \times 10^{6}-738.35 \times 10^{6} \mathrm{~kg}$ at $0-100 \mathrm{~cm}$.

When using soil taxonomy to estimate the soil organic carbon storage in karst areas, one should consider the local lateral soil heterogeneity. The high spatial heterogeneity in small karst drainage basins is extended from the vertical stratification + horizontal classification to the land use and slope aspect methods. When estimating organic carbon storage in the surficial soil $(0-20 \mathrm{~cm}$ or $0-30 \mathrm{~cm})$, the slope aspect method yields the best estimate, whereas at depths of $1 \mathrm{~m}$ the land-use method yields the best estimate.

\section{Acknowledgements}

This work was financially supported by the National Key Basic Research Development Program (grant No. 2013CB956702), the first class discipline construction project of Guizhou Province (grant No. GNYL-2017007), 100 High-Level Innovating Project (grant No. QKHRC-2015-4022), and the National Natural Science Regional Fund (grant No. 41561075).

\section{References}

1. VANDEN-BYGAART A.J., GREG E.G., ANGERS D.A., STOKLAS U.F. Uncertainty analysis of soil organic carbon stock change in Canadian cropland from 1991 to 2001. Global Change Biol. 10, 983, 2004.

2. BATJES N.H. Total carbon and nitrogen in soils of the world. Eur J Soil Sci. 47, 151, 1996.

3. BOLIN B. Change of land biota and their importance for the carbon cycle. Science. 196, 613, 1977.

4. SELMA Y.K. Effects of afforestation on soil organic carbon and other soil properties. Catena. 123 (10), 62, 2014.

5. JONES C., MC-CONNELL C., COLEMAN K., COX P., FALLOON P., Jenkinson D., Powlson D. Global climate change and soil carbon stocks; predictions from two contrasting models for the turnover of organic carbon in soil. Global Change Biol 11, 154, 2005.

6. RODRIGUEZ-MURILLO J.C. Organic carbon content under different types of land use and soil in peninsular Spain. Biol Fertil Soils. 33 (1), 53, 2001.

7. STEFFENS M., K“OLBL A., K“OGEL-KNABNER I. A1teration of soil organic matter pools and aggregation in semi-arid steppe topsoils as driven by organic matter input. Eur. J. Soil. Sci. 60, 198, 2009.

8. ZHENG H., SU Y.R., HE X.Y., HU L.N., WU J.S., HUANG D.Y., LI L., ZHAO C.X. Modified method for estimating organic carbon density of discontinuous soil in peak-karst regions in southwest China. Sci Environ Earth Sci. 67, 1743, 2012.

9. CHEN X.B., ZHENG H., ZHANG W., HE X.Y., LI L., WU J.S., HUANG D.Y,. SU Y.R. Effects of land cover on soil organic carbon stock in a karst landscape with discontinuous soil distribution. J Mt Sci. 11, 774, 2014.

10. LU X.Q., TODA H,. DING F.J., FANG S.Z., YANG W.X., XUA H.G. Effect of vegetation types on chemical and biological properties of soils of karst ecosystems. Eur J Soil Biol. 61, 49, 2014.

11. TANG Y.Q, KAI S, ZHANG X.H., ZHOU J., YANG Q., LIU Q. Microstructure changes of red clay during its loss and leakage in the karst rocky desertification area. Environ Earth Sci. 75, 10, 2016.

12. .ZHANG W., CHEN H.S., WANG K.L., SU Y.R., ZHANG J.G., YI A.J. The heterogeneity and its influencing factors of soil nutrients in peakcluster depression areas of karst region. Agric Sci China. 6, 322, 2007.

13. ZHANG J.Y., DAI M.H., WANG L.C., ZENG C.F., Su W.C. The challenge and future of rocky desertification control in karst areas in southwest China. Solid Earth Discuss.7, 3271, 2015.

14. YU D.S., ZHANG Z.Q., YANG H., SHI X.Z., TAN M.Z., SUN W.X., WANG H.J. Effect of soil sampling density on detected spatial variability of soil organic carbon in a red soil region of China. Pedosphere. 21 (2), 207, 2011.

15. SAMEREH F., SEYED M.H., SHAMSOLLAH A., ABDOLRASSOUL S. Predicting soil organic carbon density using auxiliary environmental variables in northern Iran. Archives of Agronomy and Soil Science. 62 (3), 375, 2015.

16. HE Y., WANG F., TIAN P., MU X.M., GAO P., ZHAO G.J., WU Y.P. Impact Assessment of Human Activities on Runoff and Sediment of Beiluo River in the Yellow River Based on Paired Years of Similar Climate. Pol. J. Environ. Stud. 25 (1), 126, 2016. 
17. LAL R. Soil erosion and the global carbon budget. Environ Int. 29, 437, 2003.

18. LI Z.P., HAN F.X., SU Y., JOHN P. Assessment of soil organic and carbonate carbon storage in China. Geoderma. 138, 119, 2007.

19. LIU Z.T., LIU C.Q., LANG Y.C., HU D. Dissolved organic carbon and its carbon isotope compositions in hill slope soils of the karst area of southwest China: Implications for carbon dynamics in limestone soil. Geochemical Journal. 48, 277, 2014.

20. MAO D.H., WANG Z.M., LI L., MIAO Z.H., MA W.H., SONG C.C., REN C.Y., JIA M.M. Soil organic carbon in the Sanjiang Plain of China: storage, distribution and controlling factors. Biogeosciences. 12, 1635, 2015.

21. QI Y.B., DARILEK J.L., HUANG B., ZHAO Y.C., SUN W., GU Z.Q. Evaluating soil quality indices in an agricultural region of Jiangsu Province, China. Geoderma. 149, 325, 2009.

22. TAHAR G.A., NADHEM B.B., MARTIAL B.C. Soil organic carbon density and storage in Tunisia. Global Soil Spatial Information Systems. 1, 2010.
23. HEILMAN J.L., LITVAK M.E., KEVIN J.M., KJELGAARD J.F., KAMPS R.H., SCHWINNING S. Waterstorage capacity controls energy partitioning and water use in karst 470 ecosystems on the Edwards Plateau, Texas. Ecohydrology. 7, 127, 2014.

24. LAL R. carbon sequestration impacts on global climate change and food security. Soil Sci. 304, 1623, 2004.

25. LI Y.B., XIE J., LUO G.J., YANG H., WANG S.J. The evolution of a karst rocky desertification land ecosystem and its driving forces in the Houzhaihe area. Open J Ecol. 5, $501,2015$.

26. SCHLESINGER WILLIAM H. Carbon storage in the caliches of arid soils a case study from Arizona. Soil Sci. 133, 247, 1982.

27. WANG S.Q, LIU J.Y, YU G.R. Error analysis of estimating terrestrial soil organic carbon storage in China. China $\mathrm{J}$ Appl Ecol. 14, 797, 2003.(in Chinese)

28. ZHUANG S., QIAN H., WANG F., JI H. Spatial variability of the topsoil organic carbon in the moso bamboo forests of southern China in association with soil properties. PLoS ONE. 10, 16, 2015. 